\title{
Sales Promotions and Brand Equity: The Moderating Role of Product Type
}

\author{
Zhengshun Shen \\ School of Economics and Management \\ Huaiyin Normal University \\ Huai'an, China
}

\begin{abstract}
In research of the effect of promotion on brand equity, it remains unanswered of the differential influence of monetary and non-monetary promotion on brand equity. This study examines the differential influence of the monetary and non-monetary promotion on each dimension of brand equity, and explores the moderating role of product type with hedonic and utilitarian. Findings show that product type has a different moderating role in the effect of the monetary and non-monetary promotion on each dimension of brand equity. Specifically, monetary (vs. non-monetary) promotion has more effect on brand awareness; and it has a significant influence on brand awareness, perceived quality and brand loyalty of utilitarian products than the hedonic products, but it has no significant influence on the brand association. Non-monetary (vs. monetary) promotion has more effect on brand awareness, perceived quality, and brand loyalty; and it has a significant influence on the brand association, perceived quality and brand loyalty of hedonic products than the utilitarian products, but it has no significant influence on brand awareness. Finally, this paper includes a discussion of the theoretical findings, corresponding managerial suggestions, and future research directions.
\end{abstract}

Keywords-monetary promotion; non-monetary promotion; brand equity; hedonic product; utilitarian product

\section{INTRODUCTION}

Brand equity can lead to higher sales prices, larger market shares, more effective advertising and promotion effects (Keller, 1998), faster market penetration, more leveraged product extension (Keller and Aaker, 1992), and more positive consumer perceptions and increased consumer repeat purchases, therefore to establish a strong brand in the market is a key target of enterprise business activities.

But the effective differences in quality, attributes, service and price are narrowing as competitors quickly copy innovative products. Firms are thus faced with a dilemma, on the one hand, enterprises find the effectiveness and important influence of marketing mix measures including promotional activities on brand equity creation (Yoo et al., 2000); on the other hand, the improper use of promotional activities created as brand equity has brought serious negative impact on the brand, weakening and reducing brand equity, such as making consumers' perceived value of the brand decline, affecting consumers' repurchase and so on. This reality reflects the interaction between promotional activities and brand equity.
Although there have been studies on the impact of promotional activities and brand equity, most of them are on the impact of a single promotional activity dimension on brand equity (Keller and Lehmann, 2003; Kim and Yong, 2011; Yoo et al., 2001), due to the lack of discussion on all dimensions of brand equity from the unified perspective of price promotion and non-price promotion, especially the in-depth discussion on different incentives provided by promotional activities and all dimensions of brand equity, the research conclusions obtained are often contradictory. Therefore, this study attempts to fill this research gap.

As mentioned above, based on the demand of the two aspects of theory and practice, this study explores the influence of monetary promotion and non-monetary promotion on the four dimensions of brand equity, by introducing functional products and hedonic products as a moderator variable, the moderating effects of functional products and hedonic products on the above effects were studied.

\section{ThEORETICAL ANALYSIS AND RESEARCH HyPOTHESIS}

A. The Difference Influence of Monetary and Non-Monetary Promotion on Brand Equity

1) The difference influence of monetary and non-monetary promotion on perceived quality

According to the theory of reference price, consumers set a reference price for each brand. Therefore, consumers will take the price in monetary promotion as an important external clue to infer the product quality (Agarwal and Teas, 2002). Monetary promotion leads to the reduction of internal reference prices of consumers, which makes consumers have a negative perception of brand quality.

Unlike monetary promotion, consumers tend to separate non-monetary promotion from price information and encode it as revenue (Sinha and Smith, 2000), non-monetary promotion does not lead to changes in the reference price (Palazón and Delgado-Ballester, 2009). Since consumers' reference prices are not affected by non-monetary promotion, consumers' perception of brand quality is better than that of monetary promotion in the context of non-monetary promotion.

2) The difference influence of monetary and non-monetary promotion on brand awareness

Both existing brands and new product brands tend to use brand enhancement methods such as advertising and promotion 
to increase brand awareness among existing and potential consumers (Percy et al., 1992). The visual and verbal effects of promotions can help to consolidate the brand name in consumers' memory. This means that the experience of seeing, hearing or paying attention to the brand will keep the brand rooted in memory (Radder and Huang, 2008). Monetary promotion provides consumers with the opportunity to obtain similar quality functional products at competitive prices; Non-monetary promotions enhance a brand's appeal to consumers by providing positive emotions and feelings (Buil et al., 2013). Both monetary promotion and non-monetary promotion contribute to the establishment of the relationship between the brand and consumers, so there is no significant difference in the impact of monetary promotion and non-monetary promotion on brand awareness.

3) The difference influence of monetary and non-monetary promotion on brand association

The brand association formed by consumers includes all kinds of information related to the brand, such as attributes, benefits, thoughts, emotions, experiences and so on (Keller, 1998). Therefore, brand association may be potentially affected and changed by the promotion activities. Promotion can change the number of brand associations, because promotion has the ability to enhance brand association (Palazón and Delgado-Ballester, 2005). Thus, promotion can make a significant difference to brand's unique association.

According to behavioral learning theory, monetary promotion is more likely to become the main strengthening factor for consumers to purchase products. Monetary promotion leads to the uncertainty of consumers' perception of brand quality, which is not conducive to the establishment of long-term brand association and will eventually lead to more negative brand recognition. This means that compared with non-monetary promotion, monetary promotion is less efficient in establishing brand association, because monetary promotion emphasizes price as a single brand association. In other words, monetary promotion leads consumers to consider convenience, price and transaction rather than brand (Yoo et al., 2000).

When consumers' purchase decisions have hedonic motives, fun, enjoyment or sensory stimulation will affect brand cognition. Non-monetary promotion successfully diverts consumers' attention from price. This indicates that monetary promotion only produces a relatively single functional connection because it provides practical benefits, while non-monetary promotion creates more abstract connections because it provides rich hedonic benefits. Therefore, non-monetary promotion is conducive to brand differentiation, can convey unique brand attributes, and thus improve brand association (Chu and Keh, 2006).

4) The difference influence of monetary and non-monetary promotion on brand loyalty

Frequent monetary promotion can damage brand equity. Monetary promotion not only reduces repeat purchase rate, but also affects consumer loyalty. In this study, monetary promotion can quickly improve short-term performance, such as increasing market share. In essence, monetary promotion is used to stimulate and induce consumers to try products and encourage consumers to change brands, which is not conducive to the accumulation of brand loyalty.

Consumer brand loyalty will be affected by promotion intensity (Agrawal, 1996), according to the above analysis, non-monetary promotion is conducive to the establishment of consumer brand relationship, and can convey distinctive brand attributes through non-monetary promotion, which is conducive to the development and strengthening of brand image (Joseph et al., 2009). The main purpose of non-monetary promotion activities is to pursue long-term market objectives, improve brand image and increase brand loyalty (Lee, 2002). Therefore, compared with monetary promotion, non-monetary promotion can establish higher brand loyalty.

Based on the above discussion, the following hypotheses are proposed in this study:

H1: Non-monetary promotion has a more positive impact on brand equity than monetary promotion;

H1a: Compared with monetary promotion, non-monetary promotion has a greater impact on perceived quality;

H1b: There is no significant difference between monetary promotion and non-monetary promotion on brand awareness;

H1c: Compared with monetary promotion, non-monetary promotion has a greater impact on brand association;

H1d: Compared with monetary promotion, non-monetary promotion has a greater impact on brand loyalty.

\section{B. The Moderating Effect of Product Type on the Influence of Promotion on Brand Equity}

Because consumers buy and use hedonic and functional products for different reasons, their consumption goals are essentially different (Chernev, 2004). Hedonic products can provide rich consumption experiences such as fun, pleasure and excitement, functional products mainly provide more instrumental utility (Chitturi et al., 2008). Consumers buy hedonic products to meet the pleasure and symbolic needs of the senses; instead, functional products are consumed to meet actual or functional needs. Therefore, consumers pay more attention to objective and specific information such as price. Consumer purchases of hedonic products do not involve extensive information processing (Mittal, 2006), because consumer evaluations are more comprehensive and often subjective, such as based on their own emotional responses (Botti and McGill, 2011). Therefore, consumers will be more subjective when buying hedonic products; in contrast, buying functional products is more rational. Obviously, different types of products bring different expected benefits to consumers.

Based on the above analysis, this study believes that when consumers buy hedonic products, they will be affected by subjectivity and pay more attention to the core clues related to shopping experience and pleasure emotion. In this case, the influence of peripheral clues such as price and instrumental utility on consumers is limited. When consumers buy functional products, they will be directly affected by external clues, such as price, product performance attributes to make purchase decisions. From this, it can be inferred that compared with hedonic product brands, monetary promotion that pursues 
low price and fine quality has a greater impact on the brand equity of functional products. Compared with functional product brands, non-monetary promotion that pursues pleasant shopping experience has a greater impact on brand equity of hedonic products. In conclusion, we propose the following hypothesis:

H2: product type differences play a moderating role in the impact of promotional activities on brand equity;

H2a: Compared with functional products, non-monetary promotion of hedonic products has a greater impact on perceived quality; compared with hedonic products, monetary promotion of functional products has a greater impact on perceived quality;

H2b: Compared with hedonic products, monetary promotion of functional products has a greater impact on brand awareness;

H2c: Compared with functional products, non-monetary promotion of hedonic products has a greater impact on brand association;

H2d: Compared with functional products, non-monetary promotion of hedonic products has a greater impact on brand loyalty; compared with hedonic products, monetary promotion of functional products has a greater impact on brand loyalty.

\section{RESEARCH DESIGN AND RESULT ANALYSIS}

\section{A. Experimental Design and Subjects}

2 (promotion type: monetary vs non-monetary promotion) $\times 2$ (product type: hedonic vs functional product) group experiment design was adopted. In this study, 119 students from a university were invited to participate in the experiment. After 16 subjects were excluded (7 did not participate in the experiment completely, 9 did not pass the questionnaire), 103 valid samples ( $65.0 \%$ of female) were selected.

\section{B. Stimulus Material}

To exclude any influence of previous experience and knowledge related to past promotion activities (Raghubir and Corfman, 1999), virtual brands were used in the experiments. The brand name of foreign language pronunciation plays a special role in consumer cognition (Leclerc et al., 1994). The French pronunciation brand has elegant and noble attributes, while the German pronunciation brand conveys quality and reliability, therefore, the hedonic product brand in the stimulus material is named "Le Elegant" in French pronunciation, and the functional product brand is named "HauGuner" in German pronunciation. In order to ensure the appropriateness of stimulus materials and carry out pre-test of product selection, ten MBA students were asked to provide a most frequently used hedonic product and functional product catalog, and then ten graduate students measured the product catalog with 7-level Likert scale according to familiarity. Pre-test showed that the highest score in hedonic products was perfume $(M=5.46)$, and razor was the most familiar in functional products $(\mathrm{M}=5.57)$. Therefore, the stimulating materials of this experiment are: French brand Le Elegant perfume and German brand HauGuner razor.

\section{Experimental Process}

The subjects were randomly assigned to four experimental groups, and then the reading materials provided to the subjects detailed the corresponding promotional activities. A week later, after repeating the experiment, participants were asked to rate perceived quality ( $\alpha=0.83)$, brand association $(\alpha=0.86)$, brand awareness $(\alpha=0.87)$ and brand loyalty $(\alpha=0.87)$. Finally, the questionnaire was collected and the subjects were thanked.

The measurement scale of perceived quality is from the study of Yoo et al., (2000). The measurement scale of brand association is from the study of Pappu et al., (2005). The measurement scale of brand awareness is from the study of Yoo et al., (2000). The measurement scale of brand loyalty is from the study of Yoo et al., (2000).

\section{Experimental Results and Analysis}

The paired sample t-test of monetary promotion and non-monetary promotion shows that, as shown in table 1, non-monetary promotion is more effective than monetary promotion in influencing perceived quality. $\mathrm{M}_{\text {non }}=4.19$, $\mathrm{M}_{\text {monetary }}=3.10, \mathrm{p}<0.001$, which supports H1a. There is no significant difference in the influence of monetary promotion and non-monetary promotion on brand awareness, which supports H1b. Non-monetary promotion has a more effective effect on brand association than monetary promotion, $\mathrm{M}_{\text {non }}=4.04, \mathrm{M}_{\text {montary }}=3.36, \mathrm{p}<0.05$, which supports H1c. Non-monetary promotion has a more effective effect on brand loyalty than monetary promotion, $\mathrm{M}_{\text {non }}=4.10, \mathrm{M}_{\text {monetary }}=3.73$, $\mathrm{p}<0.05$, which supports H1d.

TABLE I. THE INFLUENCE OF MONETARY AND NON-MONETARY PROMOTION ON BRAND EQUITY

\begin{tabular}{|l|l|l|l|l|}
\hline $\begin{array}{l}\text { Promotion } \\
\text { Type }\end{array}$ & $\begin{array}{l}\text { Perceived } \\
\text { Quality }\end{array}$ & $\begin{array}{l}\text { Brand } \\
\text { Awareness }\end{array}$ & $\begin{array}{l}\text { Brand } \\
\text { Association }\end{array}$ & $\begin{array}{l}\text { Brand } \\
\text { Loyalty }\end{array}$ \\
\hline Monetary & 3.10 & 4.89 & 3.36 & 3.73 \\
\hline Non-monetary & 4.19 & 4.68 & 4.04 & 4.10 \\
\hline T-test & $-3.85^{* *}$ & 2.67 & $-2.26^{*}$ & $-2.65^{*}$ \\
\hline
\end{tabular}

In the context of monetary promotion, the difference of product type has a significant impact on perceived quality $\left(\mathrm{M}_{\text {functional }}=4.92>\mathrm{M}_{\text {hedonic }}=3.48, \mathrm{p}<0.05\right)$. In the context of non-monetary promotion, $\quad \mathrm{M}_{\text {hedonic }}=4.32, \quad \mathrm{M}_{\text {functional }}=3.18$, $\mathrm{p}<0.001$, the difference of product type has a significant effect on perceived quality, which supports $\mathrm{H} 2 \mathrm{a}$.

TABLE II. INDEPENDENT SAMPLE T TEST FOR PERCEIVED QUALITY

\begin{tabular}{|l|l|l|l|l|}
\hline \multirow{2}{*}{$\begin{array}{l}\text { Perceived } \\
\text { Quality }\end{array}$} & \multicolumn{3}{|l|}{ Monetary } & \multicolumn{2}{l|}{ Non-Monetary } \\
\cline { 2 - 5 } & Hedonic & Functional & Hedonic & Functional \\
\hline Mean & 3.48 & 4.92 & 4.32 & 3.18 \\
\hline SD & 0.39 & 0.43 & 0.80 & 0.84 \\
\hline$t$ & -18.37 & 1.76 & \\
\hline$p$ & 0.02 & 0.00 & \\
\hline
\end{tabular}

In the context of monetary promotion, $\mathrm{M}_{\text {hedonic }}=3.35$, $\mathrm{M}_{\text {functional }}=4.41, \mathrm{p}<0.001$, the difference of product type has a significant impact on brand awareness. In the context of non-monetary promotion, $\mathrm{M}_{\text {hedonic }}=4.32, \mathrm{M}_{\text {functional }}=4.11, \mathrm{p}>0.05$, the difference of product type has no significant effect on brand awareness, which supports H2b. 
TABLE III. INDEPENDENT SAMPLE T TEST FOR BRAND AWARENESS

\begin{tabular}{|l|l|l|l|l|}
\hline \multirow{2}{*}{$\begin{array}{l}\text { Brand } \\
\text { Awareness }\end{array}$} & \multicolumn{3}{|l|}{ Monetary } & \multicolumn{3}{|l|}{ Non-Monetary } \\
\cline { 2 - 5 } & Hedonic & Functional & Hedonic & Functional \\
\hline Mean & 3.35 & 4.41 & 4.32 & 4.11 \\
\hline SD & 0.48 & 0.75 & 0.86 & 0.84 \\
\hline$t$ & -1.381 & 1.33 & \\
\hline$p$ & 0.00 & 0.186 & \\
\hline
\end{tabular}

In the context of monetary promotion, $\mathrm{M}_{\text {hedonic }}=3.43$, $\mathrm{M}_{\text {functional }}=3.54, \mathrm{p}>0.05$, the difference of product type has no significant effect on brand association. In the context of non-monetary promotion, $\mathrm{M}_{\text {hedonic }}=5.06, \mathrm{M}_{\text {functional }}=4.79, \mathrm{p}<0.05$, the difference of product type has a significant impact on brand association, which supports H2c.

TABLE IV. INDEPENDENT SAMPLE T TEST FOR BRAND ASSOCIATION

\begin{tabular}{|l|l|l|l|l|}
\hline \multirow{2}{*}{$\begin{array}{l}\text { Brand } \\
\text { Association }\end{array}$} & \multicolumn{3}{|l|}{ Monetary } & \multicolumn{3}{l|}{ Non-Monetary } \\
\cline { 2 - 5 } & Hedonic & Functional & Hedonic & Functional \\
\hline Mean & 3.43 & 3.54 & 5.06 & 4.79 \\
\hline SD & 0.44 & 0.32 & 0.43 & 0.41 \\
\hline$t$ & -1.39 & 5.77 & \\
\hline$p$ & 0.24 & 0.02 & \\
\hline
\end{tabular}

In the context of monetary promotion, $M_{\text {hedonic }}=3.21$, $\mathrm{M}_{\text {functional }}=4.28, \mathrm{p}<0.001$, the difference of product type has a significant impact on brand loyalty. In the context of non-monetary promotion, $\mathrm{M}_{\text {hedonic }}=4.17, \mathrm{M}_{\text {functional }}=3.03, \mathrm{p}<0.05$, the difference of product type has a significant impact on brand loyalty, which supports H2d.

TABLE V. INDEPENDENT SAMPLE T TEST FOR BRAND LOYALTY

\begin{tabular}{|l|l|l|l|l|}
\hline \multirow{2}{*}{$\begin{array}{l}\text { Brand } \\
\text { Loyalty }\end{array}$} & \multicolumn{2}{|l|}{ Monetary } & \multicolumn{2}{l|}{ Non-Monetary } \\
\cline { 2 - 5 } & Hedonic & Functional & Hedonic & Functional \\
\hline Mean & 3.21 & 4.28 & 4.17 & 3.03 \\
\hline SD & 0.54 & 0.72 & 0.69 & 0.55 \\
\hline$t$ & -8.79 & 5.78 & \\
\hline$p$ & 0.00 & 0.02 & \\
\hline
\end{tabular}

\section{E. Discussion on Experimental Results}

The results of this experiment show that product type difference can moderate the influence of promotion activities on brand equity. Specifically, monetary promotion has a greater impact on brand awareness than non-monetary promotion. Compared with hedonic products, it is more conducive to increasing brand awareness, perceived quality and brand loyalty of functional products, but has no significant influence on increasing brand association of functional products. In addition, non-monetary promotion has a significant impact on perceived quality, brand awareness and brand loyalty compared with monetary promotion. Compared with functional products, it is more conducive to improving the perceived quality and brand association of hedonic products, and it can increase brand loyalty to hedonic products, but it has no significant influence on increasing brand awareness of hedonic products.

\section{RESEARCH CONCLUSION AND PROSPECT}

This study explored the influence of different promotion type on brand equity and investigated the moderating effect of product type on the above influence. First, compared with monetary promotion, non-monetary promotion has a stronger positive impact on brand equity in perceived quality, brand association and brand loyalty. Monetary promotion has a positive impact on brand awareness compared with non-monetary promotion. Secondly, product type plays a moderating role in the influence of promotion on brand equity. Hedonic products can provide consumers with pleasant feelings and shopping experience. Non-monetary promotion is more conducive to enhance the brand equity of hedonic products. While consumers mainly pay attention to external clues such as price and performance when purchasing functional products, monetary promotion has a more significant impact on brand equity of functional products. Previous studies on the influence of promotion on brand equity were limited to monetary promotion activities, and few studies were conducted on the influence of promotion activities on the whole promotion activities including monetary and non-monetary. This study explores the impact of monetary and non-monetary promotions on brand equity, and introduces hedonic and functional product type as moderating variables, which to some extent breaks through the existing research in this subject area and opens up a new theoretical perspective.

\section{REFERENCES}

[1] Agarwal M K, Rao V R. An Empirical Comparison of Consumer-Based Measures of Brand Equity[J]. Marketing Letters, 1996, 7(3):237-247.

[2] Agarwal S, Teas R K. Cross - national applicability of a perceived quality model[J]. Journal of Product \& Brand Management, 2002, 11(4):213-236.

[3] Botti S, Mcgill A L. The Locus of Choice: Personal Causality and Satisfaction with Hedonic and Utilitarian Decisions[J]. Journal of Consumer Research, 2011, 37(6):1065-1078.

[4] Buil I, Chernatony L D, Martínez E. Examining the role of advertising and sales promotions in brand equity creation[J]. Journal of Business Research, 2013, 66(1):115-122.

[5] Chernev A. Goal-Attribute Compatibility in Consumer Choice[J]. Journal of Consumer Psychology, 2004, 14(1-2):141-150.

[6] Chitturi R, Raghunathan R, Mahajan V. Delight by Design: The Role of Hedonic Versus Utilitarian Benefits[J]. Journal of Marketing, 2008, 72(3):48-63.

[7] Chu S, Keh H T. Brand value creation: Analysis of the Interbrand-Business Week brand value rankings[J]. Marketing Letters, 2006, 17(4):323-331.

[8] Joseph J, Sivakumaran B. The Moderating Effect of Loyalty on the Relationship of Sales Promotions and Brand Equity[C]. Advances in Consumer Research - Asia-Pacific Conference Proceedings. 2009, Vol. 8:263-264.

[9] Keller, K L. Strategic Brand Management[M]. New York: Prentice-Hall, Inc; 1998.

[10] Keller, K L, Aaker, et al. The Effects of Sequential Introduction of Brand Extensions[J]. Journal of Marketing Research, 1992, 29(1):35-50.

[11] Keller, K L, Lehmann, D R. The brand value chain: Optimizing strategic and financial brand performance[J]. Marketing Management, 2003(5-6): 27-31.

[12] Kim J H, Yong $\mathrm{J} \mathrm{H}$. A model to investigate the influence of marketing-mix efforts and corporate image on brand equity in the IT software sector[J]. Industrial Marketing Management, 2011, 40(3):424-438.

[13] Leclerc F, Schmitt B H, Dubé L. Foreign branding and its effects on product perceptions and attitudes.[J]. Journal of Marketing Research, 1994, 31(2):263-270.

[14] Lee C W. Sales promotions as strategic communication: the case of Singapore[J]. Journal of Product \& Brand Management, 2002, 11(2):103-114. 
university[J]. Journal of Fashion Marketing and Management, 2008, 12(2):232-243.

[21] Raghubir P, Corfman K. When Do Price Promotions Affect Pretrial Brand Evaluations?[J]. Journal of Marketing Research, 1999, 36(2):211-222.

[22] Reynolds T J, Phillips C B. In Search of True Brand Equity Metrics: All Market Share Ain't Created Equal[J]. Journal of Advertising Research, 2005, 45(45):171-186.

[23] Sinha I, Smith M F. Consumers' perceptions of promotional framing of price[J]. Psychology \& Marketing, 2000, 17(3):257-275.

[24] Yoo B, Donthu N, Lee S. An examination of selected marketing mix elements and brand equity[J]. Journal of the Academy of Marketing Science, 2000, 28(2):195-211.

[25] Yoo B, Donthu N. Developing and validating a multidimensional consumer-based brand equity scale[J]. Journal of Business Research, 2001, 52(1):1-14. 